\title{
We need to talk: "democratic dialogue" and the ongoing saga of prisoner disenfranchisement
}

\author{
C R G Murray*
}

Lecturer, Newcastle Law School

\begin{abstract}
$\underline{\text { Abstract }}$
Challenges to prisoner disenfranchisement in the United Kingdom have persisted for more than a decade, progressing through the domestic courts to the European Court of Human Rights and back again. The issue has been subject to a prolonged two-stage consultation. And yet, in spite of the decision in Hirst $v \mathrm{UK}$ (No 2) that the current disenfranchisement regime breaches the right of prisoners to vote, the governments in office since this decision have to date declined to introduce legislation to rectify the breach. This article considers the response of the United Kingdom's domestic courts to this situation, focusing upon the general unwillingness of the courts to confront the government over the stalled reform process and the implications of this reluctance for the operation of the Human Rights Act 1998 (HRA). The prisoner enfranchisement cases give rise to important questions regarding the domestic courts' discretion to re-interpret provisions so as to bring the law within the margin of appreciation and whether multiple declarations of incompatibility should be issued if the government fails to respond to the first in an appropriate and timely manner.
\end{abstract}

Key words: prisoner disenfranchisement; right to vote; Human Rights Act; separation of powers; margin of appreciation

\section{Introduction}

$\mathrm{T}$ he issue of prisoner voting rights in the United Kingdom has remained unresolved since the decision of the European Court of Human Rights' Grand Chamber in Hirst $\mathrm{v}$ UK (No 2). ${ }^{1}$ Hirst, serving a life sentence for voluntary manslaughter, claimed that the denial of his right to vote at the 2001 general election constituted an infringement of Article 3 of Protocol 1 of the European Convention on Human Rights (ECHR), by which states "undertake to hold free elections at reasonable intervals by secret ballot, under conditions which will ensure the free expression of the opinion of the people in the choice of the legislature". Prison officials had refused his requests to be added to the register of electors on the basis of the Representation of the People Act 1983, which provides that "[a] convicted person during the time that he is detained in a penal institution in pursuance of his sentence ... is legally incapable of voting at any parliamentary or local government election". 2

* My thanks to Kevin J Brown (Newcastle University), Roger Masterman (Durham University), Richard Mullender (Newcastle University) and Aoife O'Donoghue (Durham University) for their advice and comments upon earlier drafts of this article. Any errors remain my own.

1 Hirst $\mathrm{v}$ United Kingdom (No 2), App. No 74025/01 (2006) 42 EHRR 41.

2 Representation of the People Act 1983, s. 3(1). 
Ultimately, the Grand Chamber recognised that the blanket ban on prisoner voting violated the right to vote, rejecting the United Kingdom government's suggestions that "imprisonment after conviction involves the forfeiture of rights beyond the right to liberty, and especially the assertion that voting is a privilege not a right". 3 The reform process which would ordinarily be set in motion by such a decision was, however, stymied by a pair of prolonged consultations. These consultations did not commence until over a year after the Grand Chamber's decision ${ }^{4}$ and only concluded in September 2009.5 This represents a significantly delayed and, according to Parliament's Joint Committee on Human Rights (JCHR), "disproportionate" 6 consultation process which made a mockery of the Labour government's original assurances that remedial legislation would be introduced by October $2007 .{ }^{7}$ By the time of the 2010 general election, prisoners remained unable to vote in the United Kingdom. This situation drew severe criticism from the Council of Europe's Committee of Ministers, which:

[E]xpressed profound regret that despite the repeated calls of the Committee, the United Kingdom general election was held on 6 May 2010 with the blanket ban on the right of convicted prisoners in custody to vote still in place. ${ }^{8}$

This rebuke calls into question the "hands-off" approach of the United Kingdom's domestic courts during the attenuated reform process. In evaluating their performance, this article firstly considers the Grand Chamber's decision in Hirst that the United Kingdom's blanket disenfranchisement of prisoners was incompatible with Article 3 of Protocol 1, which provided the backdrop to the domestic courts' responses to renewed challenges to the voting ban. Faced with the Labour government's protracted consultations, prisoners attempted to enforce the right to vote at various elections held in the United Kingdom (including elections for devolved institutions and European Parliament elections), confronting courts in Scotland, ${ }^{9}$ Northern Ireland, ${ }^{10}$ and England and Wales ${ }^{11}$ with the ongoing breach of their right to vote. The courts' reactions to these challenges showcase the limitations upon the remedial mechanisms established under the HRA where a government prevaricates rather than addressing an identified breach. These cases also betray the discomfort of some judges with suggestions that, under the HRA, the judiciary should engage in a "democratic dialogue" with other branches of government. ${ }^{12}$ This discomfort manifested itself in the failure of these courts to address the limitations of the existing reform proposals on prisoner enfranchisement. Therefore, if the HRA is generally regarded as being responsible for a "quantum leap into a new legal culture of fundamental rights and

3 Hirst (No 2) (2006) 42 EHRR 41, para. 75.

4 See Consultation Paper CP39/06, Voting Rights of Convicted Prisoners Detained within the United Kingdom: The UK's response to the Grand Chamber of the European Court of Human Rights judgment in Hirst $v$ United Kingdom, 14 December 2006, available at www.dca.gov.uk/consult/voting-rights/cp2906.pdf.

5 See Consultation Paper CP6/09, Voting Rights of Convicted Prisoners Detained within the United Kingdom: Second Stage Consultation, 8 April 2009, www.justice.gov.uk/consultations/docs/prisoner-voting-rights.pdf.

6 JCHR, 16th Report of 2006-07, Monitoring the Government's Response to Court Judgments Finding Breaches of Human Rights, 18 June 2007, HL Paper 128/HC 728, para. 78.

7 See Smith v Scott [2007] CSIH 9, para. 40.

8 CM/Del/Dec (2010) 1086/18, 7 June 2010, 1086th Meeting (DH).

9 Smith [2007] CSIH 9 and Traynor v Secretary of State for Scotland [2007] CSOH 78.

10 Toner and Walsh [2007] NIQB 18.

11 R (Chester) v Secretary of State for Justice [2009] EWHC 2923 (Admin).

12 See R Clayton QC, “Judicial deference and 'democratic dialogue': the legitimacy of judicial intervention under the Human Rights Act 1998” (2004) PL 33. 
freedoms", 13 the reluctance of the courts to hasten this particular reform process helps us to measure the limits of this jump.

\section{Slow progress towards prisoner enfranchisement in the UK's courts}

The now vexed issue of prisoner disenfranchisement was long neglected by the United Kingdom's courts. Reviewing Canadian and American cases on prisoners' rights in the 1970s, Graham Zellick admitted that, by contrast, within the legal systems of the United Kingdom, "the law for most purposes tends to stop at the prison gates, leaving the prisoner to the almost exclusive control of the prison authorities". ${ }^{14}$ In the 1960 s and 1970s the courts in the United States had to determine a series of cases on voting rights and the rights of offenders. These streams of jurisprudence merged in the case of Richardson $\mathrm{v}$ Ramirez ${ }^{15}$ a challenge to the continuing disenfranchisement of offenders even after their release. Although Justice Rehnquist conceded that "the more enlightened and sensible" approach to criminal justice would be to harness the rehabilitative potential of such an extension of the franchise, the Supreme Court ultimately decided to leave the issue to state legislatures. ${ }^{16}$

Whilst the ongoing disenfranchisement of offenders after their release was therefore pushed up the political agenda in the United States by such legal challenges, the dearth of similar litigation by prisoners in the United Kingdom in this era can largely be explained by the historic restrictions on their access to the courts imposed as part of the ancient concept of "civil death". ${ }^{17}$ Even after the restrictions on the ability of prisoners to access the courts were repealed, ${ }^{18}$ and despite prisoners gaining access to legal aid to fund litigation, ${ }^{19}$ the Prison Rules continued to curtail prisoners' ability to conduct their legal affairs without leave from the Home Secretary. ${ }^{20}$ The courts, until the 1980 s, remained reluctant to question the operation of the Prison Rules, ${ }^{21}$ cowed by Goddard LJ's assertion that:

It would be fatal to all discipline in prisons if governors and warders had to perform their duty always with the fear of an action before their eyes if they in any way deviated from the rules. ${ }^{22}$

The courts' prolonged failure to address prisoners' rights left the domestic legal systems increasingly out of step with other common law jurisdictions. ${ }^{23}$ Pressure on the courts' stance culminated in Lord Wilberforce's acceptance, in Raymond v Honey, 24 that "a convicted prisoner, in spite of his imprisonment, retains all civil rights which are not taken away

13 W Wade, "Human rights and the judiciary" (1998) EHRLR 520, p. 532.

14 G Zellick, "Prisoners' rights in England" (1974) 24 UTLJ 331, p. 331.

15 Richardson v Ramirez (1974) 418 US 24.

16 Ibid. p. 55.

17 For an explanation of the legal disabilities which Parliament imposed on prisoners until the Criminal Justice Act 1948, see the Forfeiture Act 1870, s. 8.

18 See Criminal Justice Act 1948, s. 70(1).

19 See Legal Aid and Advice Act 1949, s. 7. These provisions are now contained within the Access to Justice Act 1999, s.7.

20 Prison Rules 1964 (SI 1964/388), r. 34(8). This situation persisted until a prisoner complained to the European Commission of Human Rights in Knechtl v United Kingdom, App. No 4115/69, 13 YB European Convention on Human Rights 730.

21 See M Loughlin and P Quinn, "Prisons, rules and courts: a study in administrative law" (1993) 56 MLR 497, p. 501.

22 Arbon v Anderson [1943] KB 252, p. 255. In the late 1970s, Shaw LJ echoed this proposition, asserting that under the Prison Act "the courts have no defined place and no direct or immediate function" in $\mathrm{R} v$ Board of Visitors of Hull Prison ex parte St Germain [1979] 1 QB 425, p. 454.

23 See S Easton, “Constructing citizenship: making room for prisoners' rights” (2008) 30 JSWFL 127, p. 135.

24 Raymond v Honey [1983] 1 AC 1. 
expressly or by necessary implication". ${ }^{25}$ For Susan Easton, this decision and the cases which followed "brought the prisoner and prison life firmly back within the notion of citizenship and into the arena of judicial scrutiny". ${ }^{26}$ Nevertheless, governments continued to argue that rights, including the right to conduct privileged legal correspondence ${ }^{27}$ and right of access to journalists, ${ }^{28}$ became privileges for the duration of an individual's imprisonment. In response, the courts reaffirmed that, whilst imprisonment necessarily entails a curtailment of rights beyond the liberty of the individual, this does not mean that other rights are extinguished. ${ }^{29}$

When, drawing upon this sea change in the judiciary's approach to prisoner rights, three individuals held in English prisons ultimately challenged their disqualification from voting, ${ }^{30}$ they argued that the right to vote could not be removed as incidental upon imprisonment. Jack Straw, the then Home Secretary, persisted with the argument that an individual's ability to vote is a function of his or her good citizenship, asserting that detention was but "one element" of punishment and that "[r]emoval from society means removal from the privileges of society, amongst which is the right to vote for one's representative". 31 Given the courts' acceptance since Raymond v Honey that imprisonment primarily involved a deprivation of liberty, this familiar proposition appeared to place the government on unstable ground. Nonetheless, in Pearson and Martinez, the Divisional Court differentiated the right to vote from rights such as access to a journalist, with Kennedy LJ asserting that:

[There is] no reason why Parliament should not, if so minded, in its dual role as legislator in relation to sentencing and as guardian of its institutions, order that certain consequences shall follow upon conviction or incarceration without transgressing in any way the philosophy expounded in Raymond $\mathrm{v}$ Honey. ${ }^{32}$

The Divisional Court heard Pearson and Martinez less than six months after the HRA came into operation. This altered context raised the case's profile. Immediately prior to the hearing, the shadow Home Secretary, Ann Widdecombe, condemned this "darn silly" case as the upshot of permitting individuals to claim that the state had breached the ECHR in the domestic courts. ${ }^{33}$ Her comments could also be read as agitating for the rejection of the claim, especially as she skirted the sub judice rule by speaking outside Parliament. ${ }^{34}$ The Divisional Court's judgment, perhaps with one eye to the controversy surrounding the case, mirrored the US Supreme Court decision in Richardson $\mathrm{v}$ Ramirez that reform was a matter for the legislature. ${ }^{35}$ It accepted that:

25 Raymond v Honey [1983] 1 AC 1, p. 10. In making this assertion Lord Wilberforce acknowledged the influence of the Canadian Supreme Court's decision in Solosky v The Queen (1979) 105 DLR (3d) 745.

26 Easton, "Constructing Citizenship", n. 23 above, p. 136.

27 R v Secretary of State for the Home Department ex parte Leech (No 2) [1994] QB 198.

$28 \mathrm{R} v$ Secretary of State for the Home Department ex parte Simms [2000] 2 AC 115.

29 See exparte Leech [1994] QB 198, p. 209, per Steyn LJ. See also ex parte Simms [2000] 2 AC 115, p. 143, per Lord Hobhouse.

$30 \mathrm{R}$ (Pearson and Martinez) v Secretary of State for the Home Department [2001] EWHC 239 (Admin).

31 Ibid. para. 9.

32 Ibid. para. 18.

33 BBC News, 21 March 2001, http://news.bbc.co.uk/1/hi/uk/1233084.stm.

34 It should be noted that, under the sub judice rule in force at the time, a civil case could be discussed by MPs in Parliament where it related to issues of national importance. See Select Committee on Procedure, Matters Sub Judice, 4th Report of Session 1971-72, 27 June 1972, HC 298.

35 Richardson (1974) 418 US 24. 
[T] here is a broad spectrum of approaches among democratic societies [to prisoner disenfranchisement], and the United Kingdom falls into the middle of the spectrum ... its position in the spectrum is plainly a matter for Parliament not for the courts. ${ }^{36}$

\section{Hirst v UK: the breach of the right to vote}

The third claimant in Pearson and Martinez, John Hirst, remained unconvinced that his desire to vote was "darn silly". He successfully pursued his case before the European Court of Human Rights. ${ }^{37}$ The Labour government responded to this setback by requesting that the case be referred to the Grand Chamber, ${ }^{38}$ arguing once more that the punishment of being banned from voting had the effect of "enhancing civic responsibility and respect for the rule of law by depriving those who had breached the basic rules of society of the right to have a say in the way such rules were made for the duration of their sentence". ${ }^{39}$ Hirst countered that the blanket ban was disproportionate, being "unrelated to the nature or seriousness of the offence and varied in its effects on prisoners depending on whether their imprisonment coincided with an election" 40 and that, contrary to the government's assertions, it "took away civic responsibility and eroded respect for the rule of law, serving to alienate prisoners further from society". 41

Accepting that automatic disenfranchisement infringed the right to vote, the Grand Chamber evidently considered that the Labour government's stance was predicated on a concern for the general public's perceived antipathy towards prisoner enfranchisement:

There is ... no question that a prisoner forfeits his Convention rights merely because of his status as a person detained following conviction. Nor is there any place under the Convention system, where tolerance and broadmindedness are the acknowledged hallmarks of democratic society, for automatic disenfranchisement based purely on what might offend public opinion. ${ }^{42}$

As Steve Foster acknowledges, however, the Grand Chamber did not reject all voting restrictions on prisoners. Rather, "it accepted, at least in principle, that the right to vote may be lost as part of an individual sentence". ${ }^{43}$ The Grand Chamber refused to criticise the United Kingdom's argument that removal of the vote from individuals in response to their criminal conviction had the potential to encourage good citizenship. It asserted that there was "no reason in the circumstances of this application to exclude these aims as untenable or per se incompatible with the right [to vote]". ${ }^{4}$ Instead, the majority emphasised that it was the blanket nature of the disenfranchisement imposed by the Representation of the People Act 1983 which breached Article 3 of Protocol 1, on the basis that "the principle of proportionality requires a discernible and sufficient link between the sanction and the conduct and circumstances of the individual concerned". 45 These statements indicate the interplay between proportionality and margin of appreciation in Hirst. Building upon the wide margin of appreciation in this field, the Grand Chamber's approach recognised the

36 Pearson and Martinez. [2001] EWHC Admin, para. 41

37 Hirst v United Kingdom (No 2) (2004) 38 EHRR 40.

38 Hirst (No 2) (2006) 42 EHRR 41.

39 Ibid. para. 50.

40 Ibid. para. 45.

41 Ibid. para. 44.

42 Ibid. para. 70.

43 S Foster, "Reluctantly restoring rights: responding to the prisoner's right to vote" (2009) 9 HRLR 489, p. 498.

44 Hirst (No 2) (2006) 42 EHRR 41, para. 75.

45 Ibid. para. 71. 
disproportionate nature of a blanket ban but allowed states to deny the vote to particular prisoners on the basis of the seriousness or nature of their offences.

In the aftermath of Hirst, the extent of the leeway provided to states in the Grand Chamber's decision was not widely recognised. The decision was portrayed by opponents of the ban on prisoners voting as a fatal blow to the United Kingdom's disenfranchisement regime. This was certainly how Hirst was received in Ireland, where legislation was quickly enacted to end the disenfranchisement of prisoners. ${ }^{46}$ Piloting the Electoral (Amendment) Bill 2006 through the Dáil, Minister for the Environment, Heritage and Local Government, Dick Roche, could not resist highlighting the delays in the United Kingdom's legislative response to Hirst: "It is consulting; we are acting." 47 As recently as October 2008, Parliament's JCHR claimed that Hirst provided "clear guidance that individuals" fundamental human rights, including the right to vote, are not contingent on their continuing to be 'good citizens"'. 48

This interpretation did not reflect the nuance inherent in the Hirst decision. By March 2010, however, the Labour government had persuaded the JCHR to recognise that "the Grand Chamber left a broad discretion to the United Kingdom to determine how to remove the blanket ban". ${ }^{49}$ The significance of this volte-face should not be underestimated; Hirst was not the final word on prisoner voting rights. In the context of the United States, Andrew Shapiro has described the Supreme Court's refusal to rule that felon disenfranchisement was unconstitutional in Richardson $\mathrm{v}$ Ramire $2^{50}$ as condemning opponents of criminal disenfranchisement to a long-running battle through the state legislatures, achieving only "piecemeal, incremental reform". 51 Similarly, the flexibility of the Grand Chamber's decision in Hirst returned the focus of the debate over enfranchisement to the national institutions of states party to the ECHR.

\section{After Hirst: consultations and renewed legal challenges}

Using the full extent of the room for manoeuvre provided by the Hirst decision, the Labour government's response to the issue of prisoner enfranchisement was conditioned by the political imperative not to be seen as "soft on crime". ${ }^{2}$ Under the premierships of both Tony Blair and Gordon Brown, the Department for Constitutional Affairs and its successor, the Ministry of Justice issued consultation documents on reform (in December 2006 and April 2009) which suggested that the government favoured, at most, a very limited

46 For a summary of the debates leading to the enactment of the Electoral (Amendment) Act 2006 in Ireland, see C Behan and I O'Donnell, "Prisoners, politics and the polls" (2008) 48 Brit J Criminol 319, pp. 326-8.

47 D Roche, TD, Dáil Éireann Debates, vol. 624, col. 1988, 5 October 2006.

48 JCHR, 31st Report of 2007-08, Monitoring the Government's Response to Human Rights Judgments: Annual Report 2008, 7 October 2008, HL Paper 173/HC 1078, para. 58.

49 JCHR, 15th Report of Session 2009-10, Enhancing Parliament's Role in Relation to Human Rights Judgments, 9 March 2010, HL Paper 85/HC 455. para. 107.

50 Richardson (1974) 418 US 24.

51 A Shapiro, "Challenging criminal disenfranchisement under the Voting Rights Act: a new strategy" (1993) 103 Yale LJ 537, p. 564. Despite these reforms, other writers have tracked rapid increases in the number of individuals disenfranchised under these provisions in the United States from the 1970s onwards. See C Uggen and J Manza, "Democratic contraction? The political consequences of felon disenfranchisement in the United States" (2002) 67 American Sociological Review 777.

52 During the 2010 general election, many Labour candidates, particularly those facing strong Liberal Democrat challenges, campaigned on the government's refusal to extend the vote to prisoners. The national Labour Party even had to order one of its candidates to withdraw a leaflet attacking the Liberal Democrat policy of legislating to enfranchise some prisoners on the basis of Hirst. The leaflet asserted: "Do you want convicted murderers, rapists and paedophiles to be given the vote? The Lib Dems do": BBC News, 19 April 2010, available at http://news.bbc.co.uk/1/hi/uk_politics/election_2010/8630001.stm. 
enfranchisement of prisoners. These consultations proceeded on the basis that "the more serious the offence that has been committed, the less right an individual should have to retain the right to vote when sentenced to imprisonment". 53 The documents proposed that franchise restrictions would apply after a low threshold sentence and established that the government would not countenance granting the vote to prisoners serving sentences of more than four years' imprisonment. ${ }^{54}$ In Steve Foster's opinion, these proposals were "aimed at allowing the government to encroach upon the prisoner's right to vote to the maximum extent that might be allowed by the Convention and the European Court". 55

Progress towards enacting even these limited reforms was slow. After Strasbourg's first decision in Hirst ${ }^{56}$ Juliet Lyon, Director of the Prison Reform Trust, expressed her concern that the Labour government would seek to delay the enfranchisement of prisoners until after the 2005 general election. ${ }^{57}$ Five years later an exasperated JCHR asserted that the obstacle blocking the reform process was simply that the issue of prisoner enfranchisement was "legally straightforward, but politically difficult". 58 These delays returned the incompatibility of the disenfranchisement of prisoners under the ECHR to the arena of the domestic courts. Nonetheless, following Hirst, prisoners might have hoped that domestic judges would finally begin the task of "clearing the channels" of obstacles impeding the operation of the democratic process, ${ }^{59}$ rather than perpetuating the deference historically shown to Parliament regarding voting rights.

The first case to arise in the wake of Hirst occurred as a result of the refusal of an electoral registration officer to include William Smith, a prisoner held in HMP Glenochil, on the electoral register for the Scottish Parliament elections held in May 2003. Smith's appeal against this decision was not heard until late 2006. Three Court of Session judges refused to "read down" s. 3 of the Representation of the People Act 1983 to conform with the right to vote, ${ }^{60}$ but did issue a declaration of incompatibility recognising that this provision breached the ECHR. ${ }^{61}$ Soon after Smith came Toner and Walsh, ${ }^{62}$ an action bought by two prisoners held in Northern Ireland prior to the Northern Ireland Assembly elections held in March 2007. Given the Grand Chamber's recognition that the blanket disenfranchisement of prisoners breached Article 3 of Protocol 1 and the recent declaration of incompatibility issued regarding the Representation of the People Act in Smith, the claimants' challenge focused instead on invalidating Article 4 of the Northern Ireland Assembly (Elections) Order 2001. This secondary legislation set out that the franchise for Northern Ireland Assembly elections mirrored that for local elections, thereby incorporating the ban on prisoner voting. However, Gillen J recognised that the root of the problem remained the Representation of the People Act and that it would be "invidious to

53 Consultation Paper CP6/09, Second Stage Consultation, n. 5 above, p. 24.

54 Ibid.

55 S Foster, "Prisoners' rights under threat: do prisoners retain their democratic rights?" (2007) 12 Cov LJ 42, p. 49.

56 Hirst (No 2) (2004) 38 EHRR 40.

57 See M Dhami, "Prisoner disenfranchisement policy: a threat to democracy?" (2005) 5 Analyses of Social Issues and Public Policy 235, p. 238.

58 JCHR, 31st Report, n. 48 above, para. 62.

59 J H Ely, Democracy and Distrust (Cambridge, MA: Harvard University Press 1980), p. 105.

60 See Smith [2007] CSIH 9, para. 27.

61 Ibid. para. 56.

62 Toner and Walsh [2007] NIQB 18. 
invalidate an Order that would serve to disenfranchise the voting population of Northern Ireland in circumstances where the genesis of the problem manifestly lies elsewhere". ${ }^{63}$

In Toner and Walsh, the delicate position of the peace process in Northern Ireland in the wake of the St Andrews' Agreement, ${ }^{64}$ with the pending election potentially "an integral part of that progress", ${ }^{65}$ hung over the challenge to prisoner disenfranchisement. In this context, Gillen J unsurprisingly refused to "take a risk laden step which would imperil or prejudice the forthcoming election at such short notice [and] would visit hardship and detriment on the concept of good administration in Northern Ireland". 66 No such impediments weighed on the mind of Burton $\mathrm{J}$ in Chester. ${ }^{67}$ This case involved a claimant who, like John Hirst, remained imprisoned in spite of completing the minimum-term element of his life sentence. ${ }^{68}$ Peter Chester sought to register for the 2009 European Parliament elections and claimed that his right to vote had been infringed after permission to do so was denied. Burton J, giving the strong impression that he regarded this claim as a dubious use of legal aid funding, ${ }^{69}$ refused to employ either s. 3 or s. 4 of the HRA in response to the breach of the right to vote. ${ }^{70}$ In all of these cases, the government accepted that the ban on voting, imposed on all convicted criminals serving custodial sentences, breached the right to vote. The reluctance of the courts to tackle this breach, which in Chester manifested itself fully four years after the Grand Chamber's ruling in Hirst, leaves an obvious question mark hanging over the effectiveness of the HRA's remedial regime.

\section{Judicial aversion towards the HRA's re-interpretive power}

The reluctance of the courts hearing prisoner enfranchisement to use s. 3 of the HRA to create exceptions to the ban on prisoner voting under the Representation of the People Act 1983 arguably indicates a continued reticence amongst judges towards the rights of prisoners. This HRA provision requires that, "[s]o far as it is possible to do so, primary legislation and subordinate legislation must be read and given effect in a way which is compatible with the Convention rights". ${ }^{71}$ In Smith, the Registration Appeal Court of Scotland asserted that the blanket nature of the ban precluded the use of the reinterpretation provision as there was "no 'grain of the legislation' which could properly serve as a starting point for any interpretation designed to clothe some or all of such prisoners with voting rights". ${ }^{72}$ Following the reasoning of Lord Nicholls in $\mathrm{Re} S$ (Minors), ${ }^{73}$ the court considered that re-interpreting s. 3 of the Representation of the People Act so as to allow any prisoners the vote would "depart substantially from a fundamental feature of the legislation" and would amount to the court "legislating on its own account". ${ }^{74}$ Such refusals to caveat or read down these provisions, on the basis that

63 Toner and Walsh [2007] NIQB 18, para. 9(viii).

64 This agreement, published on 13 October 2006, was the culmination of negotiations to restore the devolved institutions within Northern Ireland, which had been suspended since 14 October 2002. The full text of the Agreement is available at http://web.archive.org/web/20080610001151/www.standrewsagreement.org/ agreement.htm.

65 Toner and Walsh [2007] NIQB 18, para. 9(x).

66 Ibid.

67 Chester [2009] EWHC 2923 (Admin).

68 Criminal Justice Act 2003, Sch. 22, para. 3.

69 See Chester [2009] EWHC 2923 (Admin), para. 19.

70 Ibid. paras 31 and 44.

71 HRA, s. 3(1).

72 Smith [2007] CSIH 9, para. 26. See also Ghaidan v Godin-Mendoza [2004] UKHL 30, para. 33, per Lord Nicholls.

73 Re S (Minors) (Care Order: Implementation of Care Plan) [2002] UKHL 10, para. 40.

74 Smith [2007] CSIH 9, para. 27. 
doing so would amount to a fundamental alteration of the statute, are common across the prisoner enfranchisement cases. ${ }^{75}$

This reliance on the decision in Re S (Minors) was, however, misplaced. It neglected the emphasis which the Grand Chamber in Hirst placed on the lack of parliamentary debate concerning the purpose of the voting ban (either when the modern formulation of the ban was adopted in the Representation of the People Act 1969, or since). ${ }^{76}$ This lack of reasoning behind the imposition of the ban undermines the contention that stipulating specific exceptional categories of prisoners entitled to vote conflicts with any fundamental statutory purpose. As David Feldman noted before the HRA even entered force, the courts' new interpretative power could be usefully employed to place the onus on Parliament to express its legislative intention clearly. ${ }^{77}$ Put plainly, if Parliament fails to articulate the reasoning behind a measure (whether it is enacted before or after the HRA), the courts should be able to assess its core purpose and which features of the measure are fundamental to that purpose.

Furthermore, particular groups of prisoners can be separated from the prison population as a whole. Peter Chester had served the minimum-term element of his sentence and was therefore being held not as a punishment, but on grounds of the risk which he posed to the public. ${ }^{78}$ Burton $\mathrm{J}$ rejected efforts to persuade him to address the particular issue of this category of prisoners. Succumbing to what Joseph Raz identified as the traditional judicial animus towards "partial reform", 79 Burton J considered that a reinterpretation which sought to exclude this group of prisoners from the voting ban, on the basis that removal of the vote was a punishment, would encourage further claims, leading "to piecemeal and possibly continuous amendments, without consideration by Parliament, of legislation dealing with matters of important social policy, all depending upon which claimant happened to be before the Court at any one time". ${ }^{80}$ Locating this reasoning within the approach mapped out by Lord Nicholls in $\operatorname{Re} S$ (Minors), Burton J concluded that the potential for future litigation amounted to an "important practical repercussion" militating against re-interpretation. ${ }^{81}$ Similarly, in Smith, the Registration Appeal Court accepted that:

$[T]$ here were many possible levels at which the line might be drawn for the enfranchisement or disenfranchisement of convicted prisoners in different categories, and it could be no part of this court's function to make an uninformed choice among such alternatives. ${ }^{82}$

This reasoning also consciously echoes Lord Hobhouse's speech in Bellinger v Bellinger, ${ }^{83}$ concerning whether the courts should employ s. 3 of the HRA to re-interpret "female", under s. 11(c) of the Matrimonial Clauses Act 1973, to include a transsexual woman. Rejecting this course of action, Lord Hobhouse declared that it would involve "making a legislative choice as to what precise amendment was appropriate". 84 The context of this

75 See Chester [2009] EWHC 2923 (Admin), para. 26.

76 See Hirst (No 2) (2006) 42 EHRR 41, para. 79.

77 See D Feldman, “The Human Rights Act 1998 and constitutional principles” (1999) 19 LS 165, p. 186.

78 Law Commission, Murder, Manslaughter and Infanticide, Law Comm No. 304 (2006), para. 1.58.

79 J Raz, The Authority of Law (Oxford: OUP 1979), p. 201.

80 Chester [2009] EWHC 2923 (Admin), para. 30.

81 Re S [2002] UKHL 10, para. 40. See also Re P (Adoption: Unmarried Couple) [2008] UKHL 38, para. 55, per Lord Hope.

82 Smith [2007] CSIH 9, para. 26.

83 Bellinger $\mathrm{v}$ Bellinger [2003] UKHL 21.

84 Ibid. para. 78. 
decision is, however, significant. The case of Goodwin v UK, 85 in which Strasbourg concluded that the Matrimonial Clauses Act 1973 breached Articles 8 and 12 ECHR, was decided only six months prior to the House of Lords' hearing in Bellinger. The government had accepted the decision in Goodwin and announced that it was taking steps to rectify the breach through legislation even before the House of Lords heard Bellinger. Even in Smith, decided just over a year after the Grand Chamber's decision in Hirst, the Registration Appeal Court drew attention to how quickly Parliament had reacted to Goodwin by comparison to Hirst. ${ }^{86}$

The backdrops to Bellinger and Chester are therefore markedly different. Chester was decided fully four years after Hirst. This delay may, of itself, have warranted a more purposive judicial approach to the Representation of the People Act 1983, despite the practical ramifications alluded to by Burton J. As Mary Arden has pointed out in her extrajudicial writing, even after $\operatorname{Re} S$ and Bellinger the courts are still "feeling their way towards a set of rules and canons of construction that will apply where section 3(1) is in point". 87 Chester represents a missed opportunity to refine the approach of the courts to the reinterpretive power. The ability of courts to re-interpret a provision "so far as it is possible to do so" is arguably context specific. The courts should therefore take account of factors such as the duration of the identified breach in deciding whether to re-interpret a provision. At the very least, the four years of prevarication over reform that preceded Chester should have alerted Burton $\mathrm{J}$ to the danger that his confident assertion that the provisions imposing the voting ban "are imminently to be considered by the Legislature" 88 would prove a hostage to fortune.

\section{The "mirror" principle and the HRA's re-interpretive power}

Burton J went so far as to assert in Chester that, even if he did consider s. 3 of the Representation of the People Act 1983 to be capable of re-interpretation on the basis of Hirst, he would nonetheless refuse to do so. ${ }^{89}$ Nor is he alone in this assertion, for the domestic courts assessing Hirst have uniformly rejected arguments that the Grand Chamber's decision mandated particular reforms. This unwillingness to countenance a judicial solution to the issue of prisoner disenfranchisement is therefore an unexpected side effect of Strasbourg's readiness in Hirst to grant leeway to the United Kingdom as to how to reform the voting ban. As Gillen $\mathrm{J}$ asserted in Toner and Walsh:

I am not persuaded . . . that the United Kingdom Government could and will only find the approval of the European Court in circumstances where disenfranchisement was imposed by a sentencing judge ... [ [] t is clear to me that insofar as the court ventured onto this plane, their comments were nonprescriptive and purely advisory in character. ${ }^{90}$

Such advisory comments are not, of themselves, unusual. Strasbourg rarely mandates specific reforms on the finding of a breach of a particular human right, ${ }^{91}$ particularly in

85 Goodwin v UK (2002) 35 EHRR 447.

86 Smith [2007] CSIH 9, para. 54.

87 M Arden, "The interpretation of UK domestic legislation in the light of European Convention on Human Rights jurisprudence" (2004) 25 Stat LR 165, p. 179.

88 Chester [2009] EWHC 2923 (Admin), para. 29.

89 Ibid. para. 30.

90 Toner and Walsh [2007] NIQB 18, para. 9(iii).

91 See, for example, Dickson v United Kingdom (2008) 46 EHRR 41, para. 89, where Strasbourg's Grand Chamber rejected an applicant prisoner's request to direct the United Kingdom to urgently reconsider a decision not to grant him access to artificial insemination facilities, on the basis that " $t$ the Court's function is, in principle, to rule on the compatibility with the Convention of the existing measures and it does not consider it appropriate in the present case to issue the requested direction". 
areas where the states enjoy a wide margin of appreciation. ${ }^{92}$ But mere "advice" from Strasbourg does create a problem for the operation of the HRA, and particularly the requirement under s. 2(1) that the courts must "take into account" judgments of the European Court of Human Rights in reaching their decisions. In the prisoner enfranchisement cases, this requirement was read in light of Lord Bingham's exhortation in $U_{l l a h}{ }^{93}$ that the courts should do no more than "keep pace with the Strasbourg jurisprudence as it evolves". 94 This approach has become known as the "mirror" principle, as it requires that the content of the rights incorporated under the HRA reflects the content of the ECHR rights in Strasbourg jurisprudence. ${ }^{95}$ Constrained by this principle, the domestic courts hearing the prisoner enfranchisement cases considered themselves unable to engage with the recommendations contained in Hirst, on the basis that acting upon advice, as opposed to "clear and constant" Strasbourg jurisprudence, ${ }^{96}$ risked overrunning their mandate. ${ }^{97}$

Washing his hands of the issue of prisoner disenfranchisement, Burton J quoted directly from the decision in Hirst. Strasbourg, he said, had sought to "leav[e] it to the legislature to decide on the choice of means for securing the rights guaranteed by [the ECHR]". 98 The reference to the legislature in this passage should, however, be read as an unfortunate slip by the majority in Hirst. Strasbourg's jurisprudence has never recognised that the process of bringing a law within the margin of appreciation is solely a matter for a national legislature. Rather, in cases dating back to Handyside $\mathrm{v}$ United Kingdom, ${ }^{99}$ Strasbourg has asserted that the margin of appreciation "is given both to the domestic legislator . . . and to the bodies, judicial amongst others, that are called upon to interpret and apply the laws in force". 100

Strasbourg's invocation of the margin of appreciation does not, therefore, simply provide domestic legislatures with scope for action, but also serves as an invitation to the domestic courts to consider particular measures in light of the purposes of the ECHR. Whilst the courts can decline such invitations, perhaps on the basis of deference to elected decision makers, ${ }^{101}$ doing so does not call into question their ability to act. Burton J's eagerness to leave this matter to the sole province of legislature, in spite of the delays in enacting reforms following Hirst, may nonetheless appear to be in line with the historic deference of the domestic courts regarding voting rights. Indeed, this may have been an understandable approach, had counsel not directed him to Lord Hoffmann's speech in the adoption case of $R e P .{ }^{102}$ In this case the House of Lords sought to refine the obligation to remain in line with Strasbourg jurisprudence, with Lord Hoffmann emphasising that:

When [the European Court of Human Rights] says that a question is within the margin of appreciation of a Member State, it is not saying that the decision must

92 See Hirst (No 2) (2006) 42 EHRR 41, paras 61 and 84.

93 R (Ullab) v Special Adjudicator [2004] UKHL 26.

94 Ibid. para. 20.

95 J Lewis, "The European ceiling on human rights" [2007] PL 720, p. 720.

96 To use the expression adopted by Lord Slynn in R (Alconbury Developments Ltd) v Secretary of State for the Environment, Transport and the Regions [2001] UKHL 23, para. 26.

97 It should be noted that addressing Strasbourg jurisprudence in these cases would not have brought these courts into conflict with the principles of stare decisis. See Kay and others $\mathrm{v}$ London Borough of Lambeth and others [2006] UKHL 10, para. 43, per Lord Bingham.

98 Chester [2009] EWHC 2923 (Admin), para. 50. See also Hirst (No 2) (2006) 42 EHRR 41, para. 84.

99 Handyside v United Kingdom (1976) 1 EHRR 737.

100 Ibid. para. 48.

101 See R v DPP ex parte Kebilene [2000] 2 AC 326, per Lord Hope, p. 381.

102 In re $P$ (and others) [2008] UKHL 38. 
be made by the legislature, the executive or the judiciary. That is a matter for the Member State. 103

Lord Hoffmann identified the task of developing the law within the margin of appreciation as one basis upon which the courts could depart from the "mirror" principle in appropriate cases. ${ }^{104}$ The courts hearing the prisoner enfranchisement cases, as much as the legislature, therefore had a role to play in bringing domestic law within the margin of appreciation. Instead, the pervasive influence of this principle persuaded these courts that it would not be possible to employ the HRA's re-interpretive power. These cases indicate that strict adherence to the rule in Ullah remains the safe option for High Court judges seeking to avoid accusations that they are imposing novel burdens on public authorities, even as the appellate courts move away from the rigidity of the "mirror" principle. 105

The prisoner enfranchisement cases therefore highlight the tension between the perceived functions of Strasbourg and the domestic courts. Strasbourg conceives its role as identifying breaches of the ECHR rights and that, thereafter, the onus passes to any relevant institutions of the state in breach to bring its laws into conformity with the ECHR. ${ }^{106}$ The prisoner enfranchisement cases, by contrast, indicate that many domestic judges remain reluctant to employ their powers under s. 3 of the HRA unless Strasbourg has clearly established the minimum contents of a right. These cases indicate, that even in instances, such as Hirst, where Strasbourg has provided advice as to how to bring domestic law in line with ECHR requirements, domestic judges will often seek refuge in a strict conception of the "mirror" principle to avoid having to re-interpret statutory provisions in line with such advice.

\section{Declarations of incompatibility and the separation of powers}

Even in light of the above analysis, re-interpreting the Representation of the People Act 1983 to extend the vote to exceptional categories of prisoner would have been a radical step, ${ }^{107}$ although one arguably commensurate with the importance of the right to vote. The question of whether to issue a declaration of incompatibility under s. 4 of the HRA, however, should have been much less controversial. In Bellinger, despite the government's commitment to rectify the law in light of Goodwin, Lord Nicholls concluded that the House of Lords should use its discretion to issue a declaration and "formally record that the present state of statute law is incompatible with the Convention". 108 The court in Smith followed this lead, asserting that Lord Nicholls' reasoning "applies equally, or with greater force, to this case", and declared s. 3 of the Representation of the People Act 1983 incompatible with the ECHR. ${ }^{109}$ In spite of the government's assurances that it accepted and was taking steps to rectify the law in light of Hirst, ${ }^{110}$ the court considered it necessary

103 In re P (and others) [2008] UKHL 38, para. 32.

104 Ibid, para. 31.

105 In addition to cases such as In re P and others [2008] UKHL 38 and R v Horncastle and others [2009] UKSC 14, in which the House of Lords and Supreme Court qualified the "mirror" principle, Baroness Hale adopted a flexible conception of the reasoning underpinning the principle in Gentle: "[The courts] are not free to foist upon Parliament or upon public authorities an interpretation of a Convention right which goes way beyond anything which we can reasonably foresee that Strasbourg might do": R (Gentle and another) v Prime Minister and others [2008] UKHL 20, para. 56 (emphasis added).

106 See N Krisch, "The open architecture of European Human Rights law” (2008) 71 MLR 183, pp. $213-15$.

107 See A Kavanagh, Constitutional Review under the UK Human Rights Act (Cambridge: CUP 2009), pp. 137-42.

108 Bellinger [2003] UKHL 21, para. 55.

109 Smith [2007] CSIH 9, paras 54-6.

110 Ibid. para. 51. 
to issue the declaration given that "the timetable [for reform] has indeed slipped, and slipped badly". 111

Still the Labour government did not act. By the time of the hearing in Chester the timetable for reform had slipped by a further two years. Burton J, confronted with what he regarded as the exhaustion of the system of remedies established in the HRA, considered that there was nothing more that the courts could do in these circumstances. He refused to use his discretion to issue a further declaration of incompatibility, on the basis that "there is no need for any declaration to be made by yet another court, as one has already been made which is binding on the UK Government". ${ }^{112}$ His characterisation of the declaration issued in Smith as "binding" upon the government is, however, open to question. As Gavin Phillipson asserts, a government's use of its power under the HRA to amend legislation ${ }^{113}$ to rectify a declared incompatibility "is not and cannot be guaranteed". ${ }^{114}$ Indeed, the Labour government had already expressed its intention not to fast-track reforms to the voting ban under s. 10(2) of the HRA in the wake of Smith. ${ }^{115}$ Burton J's description of the existing declaration as binding was nonetheless a useful fiction. He asserted that, because a "binding" first declaration had been made, exercising his discretion to issue a second declaration would not simply be redundant but contrary to the separation of powers:

Insofar as some pressure might have been intended to be brought to bear on the First Defendant ... to act speedily in bringing forward legislation to Parliament, that would be ... offensive to constitutional principles. ${ }^{116}$

Burton J's refusal to issue a declaration on the basis that it would jeopardise the separation of powers, while neglecting to criticise the government's failure to rectify such a long-standing breach of human rights, reveals his limited conception of the courts' role since the enactment of the HRA. Academics have frequently mapped out an extensive role for declarations of incompatibility. ${ }^{117}$ Aileen Kavanagh, for example, trumpets the ability of declarations to "grab the headlines" 118 and thereby draw public attention to abuses of human rights, whilst Richard Clayton identifies them as facilitating "democratic dialogue" between the branches of government regarding human rights. ${ }^{119}$ In the opposite camp, however, the former Court of Appeal judge Richard Buxton adopts a more mechanistic view of declarations as "principally a means of securing the reconciliation of English statute law with the requirements of the ECHR, rather than as a forensic instrument for use in a particular case". ${ }^{120}$ Buxton's view won through in Chester, underscoring the opposition

111 Smith [2007] CSIH 9, para. 43.

112 Chester [2009] EWHC 2923 (Admin), para. 34.

113 HRA, s. 10(2).

114 G Phillipson, "Deference, discretion, and democracy in the Human Rights Act era" (2007) 60 CLP 40, p. 67. Richard Buxton similarly concludes that s. 4 "envisages, though it does not mandate, remedial action", R Buxton, "The future of declarations of incompatibility" (2010) PL 213, p. 221. See also William Wade's criticism that the "executive discretion" as to how to respond to a declaration of incompatibility is "contrary to the rule of law in its most basic sense". Wade, "Human rights", n. 13 above, p. 531.

115 Chester [2009] EWHC 2923 (Admin), para. 13.

116 Ibid. para. 34.

117 For Fiona de Londras and Fergal Davis, “ $[\mathrm{t}]$ he declaration of incompatibility should be seen as a 'moment' capable of galvanizing parliamentary and popular dissent". F de Londras and F Davis, "Controlling the executive in times of terrorism: competing perspectives on effective oversight mechanisms" (2010) 30 OJLS 19 , p. 46.

118 Kavanagh, Constitutional Review, n. 107 above, p. 230.

119 Clayton, “Judicial deference”, n. 12 above, pp. 45-6. See also F Klug, “The Human Rights Act - a 'third way' or a 'third wave' Bill of Rights" (2001) EHRLR 361, p. 370.

120 Buxton, "The future of declarations of incompatibility”, n. 114 above, p. 214. 
of some judges to attempts by academic lawyers to conceptualise their role under the HRA as "a form of privileged pressure group whose function it is to raise good reasons why a litigant's interests should be respected". ${ }^{21}$ Given the institutional inertia inherent in this mind-set, it is unsurprising that some judges have sought to generate constitutional difficulties with the use of their powers under the HRA. ${ }^{122}$

The Chester decision indicates both the discretionary nature of declarations of incompatibility and the fact that declarations, where issued, are not enforceable. These factors will continue to prevent the European Court of Human Rights from accepting that declarations constitute an effective remedy. ${ }^{123}$ In Burden $\mathrm{v}$ United Kingdom, the Grand Chamber acknowledged that:

[1] $\mathrm{t}$ cannot be excluded that at some time in the future the practice of giving effect to the national courts' declarations of incompatibility by amendment of the legislation is so certain as to indicate that s. 4 of the Human Rights Act is to be interpreted as imposing a binding obligation. ${ }^{124}$

However, at that time, due to the "relatively small number of such declarations that have become final", 125 Strasbourg declined to recognise s. 4 as providing an effective remedy. Such reticence would appear to be vindicated by the saga of the prisoner enfranchisement cases. These cases affirm Conor Gearty's view that s. 4 "amounts to little more than a cry for action". ${ }^{126}$ Worse, if Burton J's refusal to use his discretion to issue a second declaration is followed by other courts, the judiciary would be limited to only ever crying out once in response to a breach of human rights, no matter how long ministers procrastinate over reform of the law.

\section{"Parliament is on the job": the courts and reform proposals}

The previous section established how a mechanistic conception of s. 4 of the HRA, as no more than a tool for identifying infringements of rights, can transform requests for multiple declarations of incompatibility into a threat to the separation of powers. This, however, is only one example of the reluctance of courts to be drawn into "democratic dialogue" in the realm of prisoner disenfranchisement. The courts hearing these cases also declined to assess the compatibility of the Labour government's reform proposals with Article 3 of Protocol 1. Beyond general criticism of the pace of reform, such as Gillen J finding "little evidence of a determination to prioritise appropriately the task that was defined by the Hirst decision", 127 the domestic courts hearing prisoner disenfranchisement since Hirst have largely relied on these proposals to counter the claims of individual prisoners. In spite of the second consultation document's recognition that "ultimately Parliament must debate and decide on the extent of the franchise", 128 the government's representatives in Chester ${ }^{129}$ (and, prior to

121 T. Hickman, "Constitutional dialogue, constitutional theories and the Human Rights Act 1998” (2005) PL 306, p. 309.

122 On the broader issue of the readiness of some courts, practitioners and commentators to identify constitutional difficulties with the role of the courts under the HRA, see Baroness Hale, speech to the Salford Human Rights Conference 2010, 4 June 2010, p. 13, available at www.supremecourt.gov.uk/docs/ speech_100604.pdf.

123 Article 35(1) ECHR.

124 Burden $\mathrm{v}$ United Kingdom (2008) 47 EHRR 38, para. 43.

125 Ibid. para. 41.

126 C Gearty, "Revisiting section 3(1) of the Human Rights Act" (2003) 119 LQR 551, p. 552.

127 Toner and Walsh [2007] NIQB 18, para. 9(ii).

128 Consultation Paper CP6/09, Second Stage Consultation, n. 5 above, p. 21.

129 See Chester [2009] EWHC 2923 (Admin), para. 14. 
the second consultation, in Toner and Walsh) ${ }^{130}$ emphasised that the claimant prisoners would not be enfranchised under proposals which would only extend the vote to individuals imprisoned for short periods. ${ }^{131}$ In Toner and Walsh, where the claimants were convicted of armed robbery and burglary respectively, Gillen J asserted that he was "singularly unconvinced that the applicants . . . will ever be able to lay claim to a right to vote". ${ }^{132}$

In contrast to this willingness to consider the proposals where they supported the government's case, in Chester the High Court refused to address the inadequacies of the reform proposals, on the basis of the constitutional convention that the courts would not ordinarily comment on proposals before Parliament. ${ }^{133}$ This convention operates alongside Article 9 of the Bill of Rights 1689, which provides that "the freedom of speech and debates or proceedings in Parlyament ought not to be impeached or questioned in any court or place out of Parlyament". Several judges have justified the convention as upholding good relations between the courts and Parliament. ${ }^{134}$ In ex parte Smedley, ${ }^{135}$ Sir John Donaldson MR followed his famous statement that "it is a constitutional convention of the highest importance that the legislature and the judicature are separate and independent of one another" 136 by declaring that one facet of convention prevented the courts from discussing proposals which were before Parliament:

$[1 \mathrm{t}$ would clearly be a breach of the constitutional conventions for this court, or any court, to express a view, let alone take any action, concerning the decision to lay this draft Order in Council before Parliament or concerning the wisdom or otherwise of Parliament approving that draft. ${ }^{137}$

Emphasising the importance of this convention in maintaining the separation of powers, ${ }^{138}$ Burton $\mathrm{J}$ concluded that the proposed reform "plainly involves a balancing act and, assuming that not all convicted prisoners are to be enfranchised, would involve difficult questions as to which side of the line disenfranchisement would fall". ${ }^{139}$ He considered that this balancing act was a task for Parliament. On this basis he asserted:

$[\mathrm{T}]$ hat any ... relief which is intended to interfere with the process by which new legislation resulting from the consultation process is now put before and debated by Parliament, is inappropriate and is not to be granted. ${ }^{140}$

This conclusion stretches the rule protecting proceedings in Parliament to protect consultation documents produced by the government, and not by Parliament, from judicial comment simply on the basis that they may, in the future, form the basis of legislation, and stands in contrast to a long history of the judiciary commenting upon or agitating on behalf of reform proposals. For example, as the Constitutional Reform Bill was introduced into

130 See Toner and Walsh [2007] NIQB 18, para. 8.

131 Consultation Paper CP6/09, Second Stage Consultation, n. 5 above, p. 24.

132 Ibid. para. 9(iv).

133 See Chester [2009] EWHC 2923 (Admin), para. 48.

134 Sedley J, as he then was, once described the convention as providing for "a mutuality of respect between two constitutional sovereignties": R v Parliamentary Commissioner for Standards ex parte Al Fayed [1998] 1 WLR 669, p. 670. See also Office of Government Commerce v Information Commissioner [2008] EWHC 774 (Admin), para. 46, per Stanley Burnton J.

135 R v HM Treasury ex parte Smedley [1985] QB 657.

136 Ibid. p. 666.

137 Ibid. In deciding ex parte Smedley the Court of Appeal did proceed to consider whether the draft Order in Council in question (concerning an undertaking regarding payments to the then European Community) would be ultra vires the European Communities Act 1972.

138 See Chester [2009] EWHC 2923 (Admin), para. 48.

139 Ibid. para. 66.

140 Ibid. para. 52. 
Parliament, senior judges actively criticised some of its proposals. ${ }^{141}$ Even more strident judicial opposition was mounted to the ouster clause contained within the Asylum and Immigration (Treatment of Claimants, etc.) Bill 2003. ${ }^{142}$ Although these examples involve extra-judicial activities, ${ }^{143}$ Burton J's reading of the convention would prevent judges from commenting on the compatibility with the ECHR of any law reform proposals which might form the basis of future legislation.

Burton J buttressed this broad interpretation of the convention against interfering with proceedings before Parliament with a selective reading of decisions such as Countryside Alliance. In this case, Lord Bingham, rejecting the Countryside Alliance's attempt to challenge the ban on fox hunting, asserted that:

The democratic process is liable to be subverted if, on a question of moral and political judgment, opponents of the Act achieve through the courts what they could not achieve in Parliament. ${ }^{144}$

Burton $\mathrm{J}$ accepted that, on the basis that prisoner disenfranchisement and fox hunting were both "matters of sensitive social policy",145 an analogy could be drawn between these cases. He therefore justified his refusal to engage in a "democratic dialogue" regarding the reform process on the basis that it accorded with the duty of the courts not to subvert the democratic process. However, this analogy glosses over the fact that prisoner enfranchisement, in contrast to fox hunting, is not an issue which has been subject to the "recently expressed views of the democratically elected legislature". ${ }^{146}$ The Representation of the People Act 1983 merely consolidated earlier legislation and later enactments such as the Representation of the People Act 2000 dealt with issues which were tangential to the voting rights of convicted prisoners. ${ }^{147}$ Moreover, Countryside Alliance involved no clear infringement of any right, with Strasbourg ultimately rejecting claims that the ban on fox hunting infringed Article $8 .{ }^{148}$ By contrast, the courts have consistently affirmed the constitutional importance of the right to vote in the United Kingdom. ${ }^{149}$ In her speech in Countryside Alliance, Baroness Hale considered that, where an identified right has been infringed, the courts cannot abdicate their role in favour of action by Parliament:

When we can make a good prediction of how Strasbourg would decide the matter, we cannot avoid doing so on the basis that it is a matter for Parliament.

Strasbourg will be largely indifferent to which branch of government was responsible for the state of the domestic law. 150

This rallying cry in favour of judicial action applies equally to the above discussion of the HRA's re-interpretive power. But if Burton J had reason to be wary of re-interpreting

141 See Lord Windlesham, "The Constitutional Reform Act 2005: the politics of constitutional reform” (2006) PL 35, p. 39.

142 See J McGarry, "Parliamentary sovereignty, judges and the Asylum and Immigration (Treatment of Claimants, etc.) Bill” (2005) 26 Liverpool LR 1, p. 9.

143 For an acknowledgment for the scope of advisory declarations as to the requirements of the law in judicial decisions, see $\mathrm{R}$ (on the application of the Campaign for Nuclear Disarmament) v Prime Minister and others [2002] EWHC 2777, para. 15, per Simon Brown LJ.

$144 \mathrm{R}$ (on the application of the Countryside Alliance and others) v Attorney General [2007] UKHL 52, para. 45.

145 Chester [2009] EWHC 2923 (Admin), para. 51.

146 Countryside Alliance [2007] UKHL 52, para. 124, per Baroness Hale.

147 See R Jago and J Marriot, "Citizenship or civic death? Extending the franchise to convicted prisoners” (2007) $5 \mathrm{Web}$ JCLI.

148 See Countryside Alliance v United Kingdom (2010) 50 EHRR SE6, para. 46.

149 See Watkins v Secretary of State for the Home Department [2006] UKHL 17, para. 26, per Lord Bingham.

150 Countryside Alliance [2007] UKHL 52, para. 125. 
s. 3 of the Representation of the People Act 1983 in Chester, he should at least have assessed whether the government's long-delayed reform proposals would have infringed the right to vote, particularly with regard to the proposals to continue the disenfranchisement of "posttariff lifers", such as the claimant. Instead, Burton $J$ withdrew from any putative constitutional dialogue. He chose, in the words of Tom Hickman, neither to "counteract protectively" against the infringement, nor to "interact productively" with the government's proposals. ${ }^{151}$ In the HRA era, in which the United Kingdom's courts have a role alongside Parliament in addressing breaches of the ECHR, the courts need to develop the constitutional convention protecting parliamentary proceedings in a manner which permits judicial comment upon the executive's reform proposals before they come before Parliament. ${ }^{152}$ Such a development would accord with the rule that in areas of "high constitutional importance" 153 the executive does not enjoy a wide discretionary area of judgment. As for Burton J's arguments against this course on the basis of the separation of powers, Parliament ultimately has the ability to depart from the recommendations of the courts regarding such reform proposals if it chooses to do so. In doing so, however, it would have to "squarely confront" the human rights concerns at issue. ${ }^{154}$

\section{Conclusion: separation of powers or splendid isolation?}

The prisoner enfranchisement cases exemplify the ambiguity which has resulted from the domestic courts' failure to develop “a clear and stable conception of the prisoner's legal status". ${ }^{155}$ Governments have been able to manipulate the continuing uncertainty of many members of the judiciary regarding the legal status of prisoners, even in the HRA era. The domestic cases examined in this article, seem to bear out Karl Llewellyn's injunction not to underestimate the potential for first instance courts to tackle cases differently from the approach adopted by the highest court, ${ }^{156}$ at least where s. 2 of the HRA is at issue. Even as appellate courts adopt ever more nuanced approaches to the issue of following Strasbourg jurisprudence, many first instance judges remain spellbound by the clarity and simplicity of the "mirror" principle expounded by Lord Bingham in Ullah. ${ }^{157}$ Such reluctance to follow all but the most obviously "clear and constant" 158 Strasbourg jurisprudence harkens back to an earlier era of jurisprudence, when judges accepted that "decisions to be made as to the public interest are not such as courts are fitted or equipped to make". 159

Furthermore, these cases emphasise the weaknesses in the system of remedies established by the HRA. Aileen Kavanagh rejects analyses of the operation of the HRA which identify "highly polarised" preferences for s. 3 or s. 4 amongst the judiciary. Instead, she asserts that judges and academics "will assess the appropriateness of the judicial choice between section 3 and section 4 in light of the facts and the context of the individual case". 160 Her conclusion, however, does not allow for the possibility that, despite the existence of a breach, the courts will use their discretion to exercise neither of these

151 Hickman, "Constitutional dialogue", n. 121 above.

152 Such judicial activity could replace, for matters within the scope of the ECHR, the moribund advisory role of the Judicial Committee of the Privy Council under the Judicial Committee Act 1833, s. 4.

153 Kebilene [2000] 2 AC 326, p. 381, per Lord Hope.

154 See R v Secretary of State for the Home Department ex parte Simms [1999] 3 All ER 400, p. 412, per Lord Steyn.

155 L Lazarus, “Conceptions of liberty deprivation” (2006) 69 MLR 738, p. 769.

156 K Llewellyn, The Bramble Bush (New York: Oceana 1951), p. 90.

157 Ullah [2004] UKHL 26.

158 Alconbury [2001] UKHL 23, para. 26.

159 Gouriet v Union of Post Office Workers [1978] AC 435, p. 482, per Lord Wilberforce.

160 Kavanagh, Constitutional Review, n. 107 above, pp. 123-4. 
choices. The case of Chester evidences the potential powerlessness of the judiciary after a first declaration of incompatibility has been issued in instances where it is subsequently ignored by ministers on the basis of political expediency. ${ }^{161}$

The failure of the HRA's system of remedies in these cases was compounded by the reluctance of the courts to consider the limitations of the reform proposals in light of the Grand Chamber's advice in Hirst. This reluctance underlines the danger in overstating the degree to which the United Kingdom's constitutional law has entered an era of "interaction" and indeed "interdependence" between the three branches of government. 162 As Rodney Austin asserts, the courts are not a monolithic institution and "the new constitutionalism is not universally embraced by the judiciary". ${ }^{163}$ Judges like Burton J appear happy to leave the role of assessing legislative proposals to Parliament's JCHR, with its "keen eyes open for any interference with human rights". ${ }^{164}$ Indeed, in the many situations where ministers respond in a timely and appropriate manner to the JCHR's often "quasi-judicial" advice, ${ }^{165}$ there is little need for judicial involvement in the process of law reform. Nonetheless, when an issue proves to be "legally straightforward, but politically difficult", 166 governments are adept at sidelining the criticisms of parliamentary committees. In such circumstances, where an issue is as important to democracy in the United Kingdom as prisoner enfranchisement, judicial decisions which remain aloof from the controversy draw less upon respect for the separation of powers, than upon a desire for splendid isolation from certain constitutional disputes. ${ }^{167}$

161 See T Campbell, "Incorporation through interpretation" in T Campbell, K Ewing and A Tomkins (eds), Sceptical Essays on Human Rights (Oxford: OUP 2001), pp. 79, 81-2.

162 Kavanagh, Constitutional Review, n. 107 above, p. 406.

163 R Austin, "The new constitutionalism, terrorism and torture" (2007) 60 CLP 79, p. 82.

164 Chester [2009] EWHC 2923 (Admin), para. 49.

165 F Klug and H Wildbore, "Breaking new ground: the Joint Committee on Human Rights and the role of Parliament in human rights compliance" (2007) EHRLR 231, p. 243.

166 JCHR, 31st Report, n. 48 above, para. 62. In such circumstances Francesca Klug and Helen Wildbore assert that "[i]t is not that the advice of the JCHR is held in less esteem than that of [other] scrutiny committees, but that Ministers are aware of the rather more discretionary and controversial nature - and values-base - of many human rights assessments": Klug and Wildbore, "Breaking new ground", n. 165 above, p. 240.

167 Subsequent to the completion of this article, the Court of Appeal heard Peter Chester's appeal from Burton J's decision (R (Chester) v Secretary of State for Justice [2010] EWCA Civ 1439). Again, the court refused to use its powers under the HRA to address prisoner disenfranchisement. It upheld the High Court's decision, with Laws LJ asserting, at para. 35, that reform of the voting ban on prisoners "is a political responsibility, and that is where it should remain". 